\title{
Serum ghrelin levels in papillary thyroid carcinoma
}

\author{
Bekir Ucan', Mustafa Sahin'2, Muhammed Kizilgul', Mustafa Ozbek', \\ Seyda Ozdemir ${ }^{3}$, Mustafa Calıskan', Erman Cakal'
}

'SBU Diskapi Yildirim Beyazit Training and Research Hospital, Department of Endocrinology and Metabolism, Ankara, Turkey ${ }^{2}$ Ankara University, School of Medicine, Department of Endocrinology and Metabolism, Ankara, Turkey ${ }^{3}$ SBU Diskapi Yildirim Beyazit Training and Research Hospital, Department of Biochemistry, Ankara, Turkey

Correspondence to: Bekir Ucan

Diskapi Hospital,

Irfan Bastug Caddesi, Ankara uzm.dr.bekir@hotmail.com

Received on Aug/17//2016 Accepted on May/15/2017

DOI: 10.1590/2359-3997000000290

\begin{abstract}
Objective: Ghrelin plays a role in several processes of cancer progression, and numerous cancer types express ghrelin and its receptor. We aimed to investigate serum levels of ghrelin in patients with papillary thyroid carcinoma (PTC) and its association with the prognostic factors in PTC. Materials and methods: We enrolled 54 patients with thyroid cancer ( 7 male, 47 female) and 24 healthy controls ( 6 male, 18 female) in the study. We compared demographic, anthropometric, and biochemical data, and serum ghrelin levels between the groups. Serum ghrelin levels were measured using as enzyme-linked immunosorbent assay. Results: Ghrelin levels were similar between the groups, but plasma ghrelin levels were significantly higher in tumors larger than $1 \mathrm{~cm}$ diameter compared with papillary microcarcinomas. Serum ghrelin levels also correlated with tumor size $(r=0.499$; $\mathrm{p}<0.001)$. Body mass index, thyroid-stimulating hormone, and HOMA-IR levels were similar between the groups. There were no statistically significant differences regarding average age and other prognostic parameters including lymph node invasion, capsule invasion, multifocality and surgical border invasion between patients with microcarcinoma and tumors larger than $1 \mathrm{~cm}$. Conclusion: In our study, no significant difference in serum ghrelin levels was determined between patients with papillary thyroid cancer and healthy controls however, serum ghrelin levels were higher in tumors larger than $1 \mathrm{~cm}$ compared to in those with thyroid papillary microcarcinoma. Arch Endocrinol Metab. 2017;61(5):464-9
\end{abstract}

\section{Keywords}

Papillary thyroid carcinoma, ghrelin, tumor size

\section{INTRODUCTION}

$\mathrm{G}$ hrelin, a 28-amino acid peptide hormone, was I discovered in 1999 as the endogenous ligand for the growth hormone secretagogue/ghrelin receptor (GHS-R) (1). Ghrelin has well-documented systemic actions including stimulation of gastrointestinal system motility; gastric acid secretion; regulation of sleep, taste sensation, and reward-seeking behavior; modulation of glucose metabolism; suppression of brown fat thermogenesis; regulation of stress and anxiety; prevention of muscle atrophy; and improvement of cardiovascular functions such as vasodilatation and cardiac contractility (2). Ghrelin was implicated in several processes of cancer progression including cell proliferation, cell migration and invasion, angiogenesis, and apoptosis, probably via an autocrine/paracrine mechanism. Pituitary adenomas, gut carcinoids, endocrine pancreatic, ovarian, endometrial, testicular, adrenocortical, prostate, renal, lung, and breast cancer were demonstrated to express ghrelin. Some reports demonstrated that ghrelin may have an inhibitory effect in the proliferation of some cancer types, including thyroid, prostate, and breast cancer, and small cell lung carcinoma (3). Thyroid follicular/ parafollicular and thyroid carcinoma cells also express ghrelin (4). The effect of thyroid hormone status on serum ghrelin concentrations was investigated in some studies. Malandrino and cols. observed that plasma ghrelin levels were significantly higher in patients with Hashimoto's thyroiditis after the levothyroxine treatment maintaining euthyroid state (5). Ruchala and cols. demonstrated ghrelin levels varied depending on hyperthyroid, hypothyroid or euthyroid state in the same patients (6). Biyikli and cols. demonstrated lower ghrelin levels in patients with euthyroid hashimoto thyroiditis (7).

Circulating ghrelin levels were demonstrated as higher in a range of cancer types including colon cancer (8), prostate carcinoma (9), ovarian carcinoma (10), and hepatocellular carcinoma (11) however, no studies have evaluated serum ghrelin levels in papillary thyroid carcinoma. We aimed to investigate serum levels of ghrelin 
in patients with papillary thyroid carcinoma (PTC) and its association with the prognostic factors in PTC.

\section{MATERIALS AND METHODS}

\section{Study population}

Fifty-four patients ( 7 male, 47 female) with PTC and 24 age-, sex-, and body mass index (BMI)-matched controls ( 6 male, 18 female) were included in the study. The mean age of the patients was $42.4 \pm 10.1$ years and the control group was $42.5 \pm 8.9$ years. Ethics committee approval and written informed consent of participants were obtained before the study. Histopathologic documents confirmed the diagnosis of PTC. Blood was collected from patients with thyroid cancer before surgery and from healthy individuals as the controls. Subjects with other cancers and autoimmune disorders, hypertension, hepatic or renal dysfunction, diabetes mellitus, or any other inflammatory or medical condition were excluded.

\section{Clinical, biochemical, and hormonal measurements}

Weight, height, waist circumference (WC), hip circumference (HC), and systolic and diastolic blood pressure (BP) were measured. WC was determined by measuring the narrowest point between the costal margin and iliac crest at the end of a normal expiration. BMI was calculated as weight $(\mathrm{kg}) /$ height $(\mathrm{m})^{2}$. After an 8-12 hour overnight fast, venipuncture was performed between 8:00 a.m. and 9:00 a.m. and blood samples were collected into plain tubes. Blood samples were centrifuged at $2500 \mathrm{~g}$ for $15 \mathrm{~min}$ within $30 \mathrm{~min}$ of collection, and serum samples were stored at $-80^{\circ} \mathrm{C}$ until required for analysis. Serum levels of glucose, insulin, low-density lipoprotein cholesterol (LDL-C), high-density lipoprotein cholesterol (HDL-C), thyroid-stimulating hormone (TSH), free T4 (fT4), antithyroglobulin (Anti-Tg) and antithyroid peroxidase (Anti-TPO) were also measured. The normal range for fT4 was $0.74-1.52 \mathrm{ng} / \mathrm{dL}$. TSH levels ranging between $0.55-4.78 \mathrm{mIU} / \mathrm{L}$ was considered normal and normal ranges for anti-Tg and anti-TPO are $0-40 \mathrm{IU} / \mathrm{mL}$ and 0-35 IU/mL, respectively.

\section{Determination of ghrelin in plasma}

Blood samples were collected into EDTA-containing tubes and then aprotinin (Phoenix Pharmaceuticals, California, USA) was added immediately. The blood was centrifuged at $1600 \times g$ for 15 minutes; after separation of the plasma, it was stored at $-80^{\circ} \mathrm{C}$ until the ghrelin assessment. Measurements of ghrelin were performed in an EPOCH system (BioTek Instruments, Inc, USA) using a commercially available enzymelinked immunosorbent assay (ELISA) kit (Phoenix Pharmaceuticals, California, USA) following the manufacturers' instructions. The test range of the ghrelin ELISA kit was 0-100 ng/mL. The specimens were run together in the same experiment.

\section{Statistical analysis}

The descriptive values for the data obtained are expressed as mean $\pm \mathrm{SD}$, numbers, and percentage frequencies. Normality was tested using the Kolmogorov-Smirnov test. In addition, the differences between the groups were analyzed using the appropriate Chi-square test. The relationships between individual numeric properties were reviewed using Pearson's correlation analysis in the patient and control groups. $p \leq 0.05$ was used as the level of statistical significance and IBM SPSS 20.0 was used to process the calculations.

\section{RESULTS}

Fifty-four patients with PTC (mean age: $42.4 \pm 10.1$ years) and 24 age-, sex-, and BMI matched controls (mean age: $42.5 \pm 8.9$ years) were enrolled in the study. BMI, WC, TSH levels and insulin resistance (HOMA-IR) were similar between the groups. There was no statistically significant difference in ghrelin levels between patients and controls $(\mathrm{p}>0.05)$ (Table 1$)$. The mean 25-hydroxyvitamin D3 levels were similar between both groups $(\mathrm{p}>0.05)$ (Table $\mathrm{l})$. Plasma ghrelin levels were significantly higher in tumors larger than $1 \mathrm{~cm}$ diameter when compared with papillary microcarcinomas $(\mathrm{p}=0.011)$ (Table 2$)$. There were no statistically significant differences regarding average age and other prognostic parameters including lymph node invasion, capsule invasion, multifocality and surgical border invasion between patients with microcarcinoma and tumors larger than $1 \mathrm{~cm}$ (Table 2). Plasma ghrelin levels were correlated with tumor size $(\mathrm{r}=0.499 ; \mathrm{p}<$ 0.001 ) (Figure 1). Ghrelin levels were not correlated with other parameters including insulin level, fasting plasma glucose, waist circumference, BMI, TSH, 25-hydroxyvitamin D3 level, and age. The proportion of Anti-Tg and Anti-TPO positivity between group with tumor $<1 \mathrm{~cm}$ versus group with tumor $>1 \mathrm{~cm}$ were similar 
Table 1. Clinical and laboratory characteristics of patients with thyroid cancer compared with controls

\begin{tabular}{|c|c|c|c|}
\hline & Controls $n=24$ & Patients $n=54$ & $\mathbf{P}$ \\
\hline Age (years) & $42.5 \pm 9$ & $42.4 \pm 10$ & NS \\
\hline BMl $\left(\mathrm{kg} / \mathrm{m}^{2}\right)$ & $28.6 \pm 2.5$ & $29.1 \pm 5.6$ & NS \\
\hline Waist (cm) & $96.3 \pm 12.1$ & $96.4 \pm 12.8$ & NS \\
\hline Waist/hip ratio & $0.90 \pm 0.04$ & $0.91 \pm 0.07$ & NS \\
\hline \multicolumn{4}{|l|}{ Gender } \\
\hline Male & 6 & 7 & NS \\
\hline Female & 18 & 47 & \\
\hline Ghrelin (ng/mL) & $44.1(26-144)$ & $46.9(28-141)$ & NS \\
\hline Fasting glucose, mg/dL & $85 \pm 10$ & $87 \pm 20$ & NS \\
\hline Insulin (mIU/L) & $12.7(5.7-19.7)$ & $11.3(9.8-12.7)$ & NS \\
\hline HOMA-IR (\%) & $2.96(0.9-5)$ & $2.5(2.1-2.9)$ & NS \\
\hline Total cholesterol, mg/dL & $193 \pm 39$ & $207 \pm 41$ & NS \\
\hline Plasma triglycerides, mg/dL & $136 \pm 17$ & $145 \pm 10$ & NS \\
\hline High density lipoprotein cholesterol (mg/dL) & $48 \pm 10$ & $52 \pm 11$ & NS \\
\hline Low-density lipoprotein cholesterol (mg/dL) & $118 \pm 33$ & $120 \pm 39$ & NS \\
\hline Calcium (mg/dL) & $9.6 \pm 0.5$ & $9.2 \pm 0.7$ & 0.035 \\
\hline Serum phosphorus (mg/dL) & $3.4 \pm 0.4$ & $3.6 \pm 0.8$ & NS \\
\hline Vitamin D3 (ng/mL) & $16.6 \pm 6$ & $14.2 \pm 7$ & NS \\
\hline TSH (mIU/L) & $1.8(1.4-2.2)$ & $2.3(1.8-2.8)$ & NS \\
\hline Anti-TPO (IU/mL) & $104(22-186)$ & $135(20-292)$ & NS \\
\hline Anti-Tg (IU/mL) & $45(8.5-82)$ & $45(22.1-67.8)$ & NS \\
\hline
\end{tabular}

BMI: body mass index; Anti-Tg: antithyroglobulin; Anti-TPO: antithyroid peroxidase; TSH: thyroid stimulating hormone T4 thyroxine; HOMA-IR: Homeostasis model assessment for insulin resistance.

\section{DISCUSSION}

Ghrelin was initially isolated from the stomach and demonstrated to robustly stimulate hormone secretion from the anterior pituitary (1). It is well-documented that ghrelin and its receptor, the growth hormone secretagogue receptor (GHSR), are expressed in a broad array of normal tissues and cancer types, and they are considered to function as autocrine/paracrine growth factors. Ghrelin stimulates proliferation in a range of cancer cells, including human hepatoma (12), human erythroleukemia (13), adrenocortical carcinoma (14), pancreatic adenocarcinoma (15), colorectal cancer (16), choriocarcinoma (17), prostate cancer (18), breast cancer (19), and endometrial cancer cell lines (20). Ghrelin regulates apoptosis in cancer. It was shown that ghrelin treatment inhibited apoptosis in endometrial cancer (20), pheochromocytoma (21), and adrenocortical carcinoma cell lines (22). Ghrelin stimulates cell migration and invasion in pancreatic cell lines (15), colorectal cell lines (16), and astrocytoma cells (23).

Nikolopoulos and cols. observed that patients with colon cancer had significantly higher levels of total serum ghrelin. Patients with end-stage disease and patients with poorly differentiated tumors had statistically significantly higher serum total ghrelin levels (8). In contrast to this finding, a study demonstrated that serum ghrelin levels were lower in patients with colorectal carcinoma compared with healthy controls, and patients with end-stage disease had lower ghrelin levels (24). Serum levels of active ghrelin were significantly higher in patients with prostate (18), ovarian (10), and hepatocellular carcinoma (11). Major hyperghrelinemia was observed in end-stage well-differentiated neuroendocrine carcinomas (25). Corbetta and cols. indicated that plasma ghrelin concentrations in patients with gastroenteropancreatic tumors were similar to healthy controls (26). Lin and cols. demonstrated that ghrelin could activate Snail function, thus promoting renal cell carcinoma metastasis, and was associated with unfavorable prognosis (27). Altogether, although there have been a few studies with conflicting results, most studies demonstrated that several cancer tissues expressed and released ghrelin, and it played a role in cancer progression. 


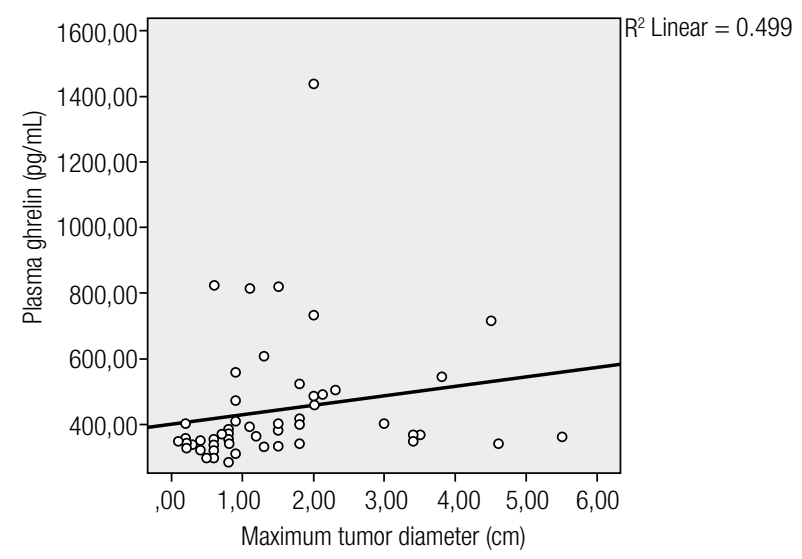

Figure 1. Correlation of tumor size with plasma ghrelin levels.

Table 2. Comparison of clinical features and prognostic factors according to tumor size

\begin{tabular}{|c|c|c|c|}
\hline & $\begin{array}{c}\text { Group with } \\
\text { tumor size } \\
<1 \mathrm{~cm}\end{array}$ & $\begin{array}{c}\text { Group with } \\
\text { tumor size } \\
>1 \mathrm{~cm}\end{array}$ & $\mathrm{p}$-value \\
\hline Age (years) & $41.66 \pm 10.52$ & $43.07 \pm 9.91$ & 0.615 \\
\hline \multicolumn{4}{|l|}{ Gender } \\
\hline $\mathrm{F}$ & 25 & 22 & \multirow{2}{*}{0.224} \\
\hline M & 2 & 5 & \\
\hline \multicolumn{4}{|c|}{ Central lymph node positivity } \\
\hline Yes & 9 & 11 & \multirow{2}{*}{0.573} \\
\hline No & 18 & 16 & \\
\hline \multicolumn{4}{|l|}{ Capsule invasion } \\
\hline Yes & 3 & 6 & \multirow{2}{*}{0.273} \\
\hline No & 24 & 21 & \\
\hline \multicolumn{4}{|l|}{ Multifocality } \\
\hline Yes & 5 & 11 & \multirow{2}{*}{0.073} \\
\hline No & 22 & 16 & \\
\hline \multicolumn{4}{|l|}{ Lymphadenopathy } \\
\hline Yes & 4 & 5 & \multirow{2}{*}{0.668} \\
\hline No & 23 & 21 & \\
\hline \multicolumn{4}{|c|}{ Surgical border invasion } \\
\hline Yes & 0 & 2 & \multirow{2}{*}{0.149} \\
\hline No & 27 & 25 & \\
\hline Ghrelin (ng/mL) & $374.63 \pm 105.66$ & $507.26 \pm 237.48$ & 0.011 \\
\hline Tumor Size (cm) & $0.56 \pm 0.26$ & $2.34 \pm 1.19$ & $<0.0001$ \\
\hline TSH (mlU/L) & $1.61(0.01-9.90)$ & $1.11(0.02-28.80)$ & 0.572 \\
\hline FT4 (ng/dL) & $1.09(0.82-1.44)$ & $1.27(0.50-1.97)$ & 0.169 \\
\hline Anti TPO (IU/mL) & $\begin{array}{c}39.00(1.14- \\
1300.00)\end{array}$ & $\begin{array}{c}33.30(0.80- \\
1000.00)\end{array}$ & 0.916 \\
\hline Anti-Tg (IU/mL) & $\begin{array}{c}30.00(10.00- \\
336.00)\end{array}$ & $\begin{array}{c}20.00(0.90- \\
500.00)\end{array}$ & 0.375 \\
\hline
\end{tabular}

Ghrelin expression in the thyroid is related to follicular and parafollicular cells. The association between ghrelin and thyroid cancer has been investigated in a few preclinical and clinical studies. Thyroid carcinomas (medullar, follicular, and papillary) in rats were demonstrated to express ghrelin (28). Ghrelin and GHSR were expressed in human thyroid carcinoma cells $(4,29)$. Volante and cols. also showed that cell proliferation of thyroid carcinoma cells was inhibited by ghrelin (29). Another study demonstrated that although ghrelin alone did not stimulate cell proliferation in thyroid cell lines, it augmented the effects of thyroid stimulating hormone on cell proliferation (30). A recent study demonstrated that ghrelin expression was similar in patients with medullary cancer, papillary cancer, and nodular goiter (31). Karaoglu and cols. indicated that ghrelin tissue levels were lower in papillary carcinoma cells compared with non-cancerous thyroid tissues (32). Morpurgo and cols. reported that ghrelin levels were similar in patients with medullary thyroid cancer and healthy controls (33). We found that ghrelin levels were similar in patients with PTC and controls; however, ghrelin levels were higher in patients with tumor size larger than $1 \mathrm{~cm}$ compared with papillary microcarcinoma. The prognostic importance of tumor size in PTC is well documented (34).

Endogenous ghrelin stimulates the release of $\mathrm{GH}$, which regulates IGF- 1 concentrations $(35,36)$. IGF-1 has mitogenic and antiapoptotic properties (37). Thyroid carcinoma cell lines contain IGF-1 receptors (38). GH might also exert a mitogenic effect by directly inducing c-myc expression (39). In light of this information, we aimed to investigate serum ghrelin levels in papillary thyroid cancer and its association with prognostic factors. We found no difference in ghrelin levels; however, serum ghrelin levels were correlated with tumor size, which is known as an important prognostic factor.

Additionally, decreased vitamin D deficiency and increased HOMA-IR index have been found associated with thyroid cancer (40). Therefore, we evaluated levels of vitamin D3 and the HOMA-IR index. However, we found no relationship between ghrelin and these parameters.

To the best of our knowledge, this is the first study to investigate serum ghrelin levels in patients with PTC. There are some minor limitations to this study such as the relatively small sample size and its single-center design. The presence of thyroiditis could have some influence in ghrelin levels however, it wasn't analyzed. Additionally, we did not investigate ghrelin receptor 
expression and its association with plasma ghrelin levels, which would have increased the strength of our study.

In conclusion, no significant difference in serum ghrelin levels was determined between patients with papillary thyroid cancer and healthy controls however, serum ghrelin levels were higher in patients with papillary thyroid cancer with larger tumor size. Further prospective studies investigating ghrelin expression and its association with serum ghrelin levels could be helpful to clarify this issue.

Acknowledgement: none.

Funding statement: none.

Disclosure: no potential conflict of interest relevant to this article was reported.

\section{REFERENCES}

1. Kojima M, Hosoda H, Date $Y$, Nakazato M, Matsuo H, Kangawa K. Ghrelin is a growth-hormone-releasing acylated peptide from stomach. Nature. 1999;402(6762):656-60.

2. Müller TD, Nogueiras R, Andermann ML, Andrews ZB, Anker SD, Argente J, et al. Ghrelin. Mol Metab. 2015;4(6):437-60.

3. Chopin L, Walpole C, Seim I, Cunningham P, Murray R, Whiteside E, et al. Ghrelin and cancer. Mol Cell Endocrinol. 2011;340(1):65-9.

4. Cassoni P, Papotti M, Catapano F, Ghè $C$, Deghenghi R, Ghigo $E$, et al. Specific binding sites for synthetic growth hormone secretagogues in non-tumoral and neoplastic human thyroid tissue. J Endocrinol. 2000;165(1):139-46.

5. Malandrino N, Miceli A, Leggio L, Mingrone G, Capristo E. High ghrelin levels in post-treatment euthyroid patients with Hashimoto's thyroiditis: a case-control preliminary study. Exp Clin Endocrinol Diabetes. 2014;122(9):540-3.

6. Ruchala M, Gurgul E, Stangierski A, Wrotkowska E, Moczko J. Individual plasma ghrelin changes in the same patients in hyperthyroid, hypothyroid and euthyroid state. Peptides. 2014;51:31-4.

7. Biyikli HH, Arduc A, Isik S, Ozuguz U, Caner S, Dogru F, et al. Assessing the Relationship Between Serum Ghrelin Levels and Metabolic Parameters and Autoimmunity in Patients with Euthyroid Hashimoto's Thyroiditis. Endocr Pract. 2014;20(8):818-24.

8. Nikolopoulos D, Theocharis S, Moutsios-Rentzos A, Kouraklis G, Kostakis $A$. The role of serum total ghrelin level elevation in colon cancer patients. J BUON. 2014;19(2):388-93.

9. Malendowicz W, Ziolkowska A, Szyszka M, Kwias Z. Elevated blood active ghrelin and unaltered total ghrelin and obestatin concentrations in prostate carcinoma. Urol Int. 2009;83(4):471-5.

10. Markowska A, Ziółkowska A, Jaszczyńska-Nowinka K, Madry R, Malendowicz LK. Elevated blood plasma concentrations of active ghrelin and obestatin in benign ovarian neoplasms and ovarian cancers. Eur J Gynaecol Oncol. 2009;30(5):518-22.

11. Ataseven $\mathrm{H}$, Bahcecioglu IH, Kuzu N, Yalniz M, Celebi S, Erensoy A. The levels of ghrelin, leptin, TNF-alpha, and IL-6 in liver cirrhosis and hepatocellular carcinoma due to HBV and HDV infection. Mediators Inflamm. 2006;2006(4):78380.
12. Murata $M$, Okimura $Y$, lida $K$, Matsumoto $M$, Sowa $H$, Kaji $H$, et al. Ghrelin modulates the downstream molecules of insulin signaling in hepatoma cells. J Biol Chem. 2002;277(7):5667-74.

13. De Vriese C, Grégoire F, De Neef $P$, Robberecht $P$, Delporte C. Ghrelin is produced by the human erythroleukemic HEL cell line and involved in an autocrine pathway leading to cell proliferation. Endocrinology. 2005;146(3):1514-22.

14. Barzon L, Pacenti M, Masi G, Stefani AL, Fincati K, Palù G. Loss of growth hormone secretagogue receptor $1 \mathrm{a}$ and overexpression of type $1 \mathrm{~b}$ receptor transcripts in human adrenocortical tumors. Oncology. 2005;68(4-6):414-21.

15. Duxbury MS, Waseem T, Ito $H$, Robinson MK, Zinner MJ, Ashley $\mathrm{SW}$, et al. Ghrelin promotes pancreatic adenocarcinoma cellular proliferation and invasiveness. Biochem Biophys Res Commun. 2003;309(2):464-8.

16. Waseem T, Javaid-Ur-Rehman, Ahmad F, Azam M, Qureshi MA. Role of ghrelin axis in colorectal cancer: a novel association. Peptides. 2008;29(8):1369-76.

17. Rak-Mardyła A, Gregoraszczuk E. Effect of ghrelin on proliferation, apoptosis and secretion of progesterone and hCG in the placental JEG-3 cell line. Reprod Biol. 2010;10(2):159-65.

18. Jeffery PL, Herington AC, Chopin LK. Expression and action of the growth hormone releasing peptide ghrelin and its receptor in prostate cancer cell lines. J Endocrinol. 2002;172(3):R7-11.

19. Jeffery PL, Murray RE, Yeh AH, McNamara JF, Duncan RP, Francis $\mathrm{GD}$ et al. Expression and function of the ghrelin axis, including a novel preproghrelin isoform, in human breast cancer tissues and cell lines. Endocr Relat Cancer. 2005;12(4):839-50.

20. Fung JN, Seim I, Wang D, Obermair A, Chopin LK, Chen C. Expression and in vitro functions of the ghrelin axis in endometrial cancer. Horm Cancer. 2010;1(5):245-55.

21. Yang M, Hu S, Wu B, Miao $Y$, Pan $H$, Zhu S. Ghrelin inhibits apoptosis signal-regulating kinase 1 activity via upregulating heat-shock protein 70. Biochem Biophys Res Commun. 2007;359(2):373-8.

22. Delhanty PJ, van Koetsveld PM, Gauna C, van de Zande B, Vitale $\mathrm{G}$, Hofland LJ, et al. Ghrelin and its unacylated isoform stimulate the growth of adrenocortical tumor cells via an anti-apoptotic pathway. Am J Physiol Endocrinol Metab. 2007;293(1):302-9.

23. Dixit VD, Weeraratna AT, Yang $H$, Bertak D, Cooper-Jenkins A, Riggins GJ, et al. Ghrelin and the growth hormone secretagogue receptor constitute a novel autocrine pathway in astrocytoma motility. J Biol Chem. 2006;281(24):16681-90.

24. D’Onghia V, Leoncini R, Carli R, Santoro A, Giglioni S, Sorbellini $F$, et al. Circulating gastrin and ghrelin levels in patients with colorectal cancer: correlation with tumour stage, Helicobacter pylori infection and BMI. Biomed Pharmacother. 2007;61(23):137-41.

25. Walter T, Chardon L, Hervieu V, Cohen R, Chayvialle JA, Scoazec $J Y$, et al. Major hyperghrelinemia in advanced well-differentiated neuroendocrine carcinomas: report of three cases. Eur J Endocrinol. 2009;161(4):639-45.

26. Corbetta S, Peracchi M, Cappiello V, Lania A, Lauri E, Vago $L$, et al. Circulating ghrelin levels in patients with pancreatic and gastrointestinal neuroendocrine tumors: identification of one pancreatic ghrelinoma. J Clin Endocrinol Metab. 2003;88(7):3117-20.

27. Lin TC, Liu YP, Chan YC, Su CY, Lin YF, Hsu SL et al. Ghrelin promotes renal cell carcinoma metastasis via Snail activation and is associated with poor prognosis. J Pathol. 2015;237(1):50-61.

28. Raghay K, García-Caballero T, Nogueiras R, Morel G, Beiras A, Diéguez $\mathrm{C}$, et al. Ghrelin localization in rat and human thyroid and parathyroid glands and tumours. Histochem Cell Biol. 2006;125(3):239-46. 
29. Volante M, Allia E, Fulcheri E, Cassoni P, Ghigo E, Muccioli G, et al. Ghrelin in fetal thyroid and follicular tumors and cell lines. Am J Pathol 2003;162(2):645-54.

30. Park YJ, LeeYJ, Kim SH, Joung DS, Kim BJ, So I, et al. Ghrelin enhances the proliferating effect of thyroid stimulating hormone in FRTL-5 thyroid cells. Mol Cell Endocrinol. 2008;285(1-2):19-25.

31. Gurgul E, Kasprzak A, Blaszczyk A, Biczysko M, Surdyk-Zasada $J$, Seraszek-Jaros A, et al. Ghrelin and obestatin in thyroid gland-immunohistochemical expression in nodular goiter, papillary and medullary cancer. Folia Histochem Cytobiol. 2015;53(1):19-25.

32. Karaoglu A, Aydin S, Dagli AF, Cummings DE, Ozercan IH, Canatan $\mathrm{H}$, et al. Expression of obestatin and ghrelin in papillary thyroid carcinoma. Mol Cell Biochem. 2009;323(1-2):113-8.

33. Morpurgo PS, Cappiello V, Verga U, Vicentini L, Vaghi I, Lauri $\mathrm{E}$, et al. Ghrelin in human medullary thyroid carcinomas. Clin Endocrinol (Oxf). 2005;63(4):437-41.

34. Hay ID, Bergstralh EJ, Goellner JR, Ebersold JR, Grant CS. Predicting outcome in papillary thyroid carcinoma: development of a reliable prognostic scoring system in a cohort of 1779 patients surgically treated at one institution during 1940 through 1989. Surgery. 1993;114(6):1050-7.

35. Jeffery PL, Herington AC, Chopin LK. The potential autocrine/ paracrine roles of ghrelin and its receptor in hormone-dependent cancer. Cytokine Growth Factor Rev. 2003;14(2):113-22.

36. Clemmons DR. The relative roles of growth hormone and IGF-1 in controlling insulin sensitivity. J Clin Invest. 2004;113(1):25-7.

37. Khandwala HM, McCutcheon IE, Flyvbjerg A, Friend KE. The effects of insulin-like growth factors on tumorigenesis and neoplastic growth. Endocr Rev. 2000;21(3):215-44.

38. Yashiro T, Ohba Y, Murakami H, Obara T, Tsushima T, Fujimoto $Y$, et al. Expression of insulin-like growth factor receptors in primary human thyroid neoplasms. Acta Endocrinol (Copenh). 1989;121(1):112-20.

39. Murphy LJ, Bell Gl, Friesen HG. Growth hormone stimulates sequential induction of c-myc and insulin-like growth factor expression in vivo. Endocrinology. 1987;120(5):1806-12.

40. Sahin M, Uçan B, Ginisç Z, Topaloğlu O, Güngünesç A, Bozkurt $\mathrm{NC}$, et al. Vitamin D3 levels and insulin resistance in papillary thyroid cancer patients. Med Oncol. 2013;30(2):589. 